\title{
Train Driving Parameters Optimization to Maximize Efficiency and Fuel Consumption
}

\section{Miloš Milovančević1, Dragan Milčićé, Boban Andjelkovic ${ }^{3}$, Ljubomir Vračar ${ }^{4}$}

\author{
${ }^{1}$ University of Niš, Faculty of Mechanical Engineering, \\ Aleksandra Medvedeva 14, 18000 Niš, Serbia \\ milos.milovancevic@masfak.ni.ac.rs \\ ${ }^{2}$ University of Niš, Faculty of Mechanical Engineering, \\ Aleksandra Medvedeva 14, 18000 Niš, Serbia; dragan.milcic@masfak.ni.ac.rs \\ ${ }^{3}$ University of Niš, Faculty of Mechanical Engineering, \\ Aleksandra Medvedeva 14, 18000 Niš, Serbia \\ boban.andjelkovic@masfak.ni.ac.rs \\ ${ }^{4}$ University of Niš, Faculty of Electronic Engineering, \\ 18000 Niš, Serbia; ljubomir.vracar @elfak.ni.ac.rs
}

\begin{abstract}
Progress in air and fuel management has greatly increased the efficiency of modern automotive train diesel engines, also achieving significant reductions of pollutant emissions. The increased flexibility of the air and fuel management systems also means a higher number of control parameters and complex interactions between different parameters. The task of tuning the engine control parameters to find the right combination to maximize the efficiency and reduce pollutant emissions is referred to as engine calibration. The task of engine calibration for modern automotive diesel engine has become extremely challenging, requiring large amount of time and money to be spent on engine test bench. The main aim of the study was to test and evaluate driving quality of train diesel engine. The subject of this test is a diesel engine train. The diesel engine train series was made with respect to running safety and dynamic behavior, under the test conditions fulfilled. It meets the prescribed requirements of the standard EN 14363: 2005.
\end{abstract}

\section{Introduction}

Energy consumption is one of the focus points of modern train operation. In the last decade, almost every train company has taken measures to diminish its carbon footprint, and to save energy. Railways are considered energy efficient compared 
to other transport modes such as air travelling. These energy reduction goals also affect high-speed railways (HSR), which are expanding throughout the world. The progress in air and fuel management has greatly increased the efficiency of modern automotive train diesel engines, also achieving significant reductions of pollutant emissions. Many studies have been carried out with regard to this issue, in order to reduce the HSR energy consumption. As the operational speed of HSR is much faster than metro train, the efficiency of the HSR can't be ensured only by traditional automatic driving methods, which increase the energy consumption and impair the intelligence of train operation. Increased flexibility of the air and fuel management systems also means a higher number of control parameters and complex interactions between different parameters. The task of tuning the engine control parameters to find the right combination to maximize the efficiency and reduce pollutant emissions is referred to as engine calibration. The task of engine calibration for modern automotive diesel engine has become extremely challenging, requiring large amount of time and money to be spent on engine test bench.

The study [1] defines a set of key performance indicators (safety, timeliness, energy consumption, workload of the driver, environment, cost of maintenance and brand image) relevant to train operation that are specific, measurable, assignable, realistic and time-related, and that are influenced by the driving strategy of the driver. The results show that a maximal coasting strategy causes the least environmental pollution, and in most scenarios its energy consumption coincided with the optimal energy-efficient train control strategy or it had an energy efficiency close to the optimal one. Eco-driving is an energy efficient traffic operation measure that may lead to important energy savings in high-speed railway lines [2, 3, 4]. Rail operations are housed inside a complex and extremely dynamic system where work is distributed in time and space [5]. Finding the way to reduce environmental impact and to produce cleaner energy is the main task of engine manufacturers. Hence, the paper [6] presents different methods and systems of diesel emission control, especially exhaust gas recirculation (EGR) techniques that regulate emissions during their formation, as well as exhaust after treatment techniques which reduce already generated harmful emissions based on the catalytic effect of precious metals, various catalytic converters and particle filtering (DPF). The article 7 has developed and evaluated two models to predict instantaneous exhaust emissions of $\mathrm{CO}_{2}$, NOx, particle number concentration and geometric mean diameter in accumulation mode $(30-560 \mathrm{~nm})$ and in nucleation mode $(5.6-30 \mathrm{~nm})$ of a 2.0 euro 4 diesel engine fueled with pure diesel and animal fat in different proportions. Today, diesel engines are no longer mentioned for generating huge amount of soot and high-level of noise. These achievements have been made owing to the employment of numerous mechatronic systems implemented in the engine [8]. Potential of an artificial neural network platform to emulate the performance, emissions and stability indices of an existing single cylinder diesel engine operating in dual-fuel mode with methanol port injection under varying fuel injection pressure has been explored in articles $[9,10,11,12,13,14]$. The main aim of the study was to test and evaluate driving quality of train diesel engine. The subject of this test is 
a diesel engine train - DMV manufactured in "Metrovagonmaš" for Serbian Railways. Testing was conducted in respect to a vibration dumping based on research $[15,16]$ in order to determent driving stability as well as vibration.

\section{Methodology}

\subsection{Experimental Testing Procedure of Diesel Engine Train Series 711}

The subject of this test is a diesel engine train - DMV conducted by simplified method and partial procedure according to standard: EN14363. This test was conducted in accordance with the methodology and criteria of the standard: EN14363 -testing for the acceptance of running characteristics of railway vehicles.

The test was conducted on the first train set in the series. Set of diesel engine train is composed of two motor wagons for passengers. Each of the two motor wagons have two axle bogies and the control room in front. Bogies in frontside of the driver's cabs have driving axels, while the axels at the side of the clutch are not driving. Train has four bogies in total. Acceleration in the lateral direction was measured on the two bogies frame.

\subsection{Test Conditions}

The test was carried out by a simplified method, i.e. measuring vertical and lateral acceleration of the bogie frame.

The procedure was applied according to the standard EN 14363. The test speed of train in both directions, while large radius track $(\mathrm{R}>2500 \mathrm{~m})$ was:

$$
V_{i s p}=1,1 \times V_{\text {max }}=1,1 \times 100 \mathrm{~km} / \mathrm{h}=110 \mathrm{~km} / \mathrm{h}
$$

If it was not possible to achieve testing speed since the maximum speed allowed, in some sections, was considerably smaller. Maximum lateral acceleration at the level of the upper edge of rail needs to be in the limits of $0.81 \div 1.19 \mathrm{~m} / \mathrm{s}^{2}$, for this type of train and the range of speeds according to EN 14363, annexes G.

Running safety and ride quality testing was performed according to EN 14363. Information about the test:

- Train number: $711-001 / 101$

- Type of vehicle: Two diesel engine train

- Manufacturer: "Metrovagonmaš"

- Net weight train: $\mathrm{m}_{0}=87.663 \mathrm{t}$ 
- Maximum train speed: $\mathrm{V}_{\max }=100 \mathrm{~km} / \mathrm{h}$

- Centre bolt distance: $2 \mathrm{a}=15,000 \mathrm{~mm}$

- Number of driving units: 2

- Number of bogies by driving units: 2

- Type of bogies: Twin axle with two-stage suspension

- Primary suspension: Double coil springs

- Secondary Suspension: Air

- Primary oscillation damping: Vertical hydraulic dampers

- Secondary oscillation damping: Vertical and horizontal hydraulic dampers

- Leading axle: Pivot

\subsection{Geometric Quality of Track}

According to EN14363 quality rail track for testing is evaluated through a standard deviation prominence of the left and right rails by profile (vertical deviation - $\mathrm{z}$ ) and deviation per direction (lateral deviation - y). Levels of quality tracks are marked with QN1, QN2 and QN3. The recommendation of EN14363 of the test track includes:

- $\quad 50 \%$ of quality sections better than or equal to QN1,

- $\quad 40 \%$ of the quality sections between QN1 and QN2,

- $\quad 10 \%$ of cut quality between QN2 and QN3.

The segments in which the deviation has exceeded maximum allowed by quality $\mathrm{QN} 3$, was not considered in the assessment of the results. The value of 1.3xQN2 was taken as the limit of QN3. Limit values for evaluating the quality of tracks depends on the maximum constructive speed of the tested vehicle Vmax. In the straight tracks and tracks with large curve radius maximum testing speed was $\mathrm{V}$ $\max +10 \mathrm{~km} / \mathrm{h}$. In the small curves radius $(\mathrm{R} \leq 600 \mathrm{~m})$, a testing speed of $80 \mathrm{~km} / \mathrm{h}<$ $\mathrm{V} \leq 120 \mathrm{~km} / \mathrm{h}$ was applicable. An overview of the relevant track parameters is shown in Table 1.

Railways Serbia used for measuring the geometric parameters gauge measuring the round: Plasser \& Theurer type EM - 80 L. Assessment of the geometric quality of the tracks on Serbia Railways is performed according to: "Instruction 339 on unique criteria for the control of the condition of the railways, while recording the following parameters: stability of the left and right rails, which corresponds to the parameter of uneven rail profiles in the vertical direction. 
Table 1

An overview of the relevant track parameters

\begin{tabular}{|c|c|c|c|c|c|c|}
\hline \multirow[t]{2}{*}{ parameters track } & \multicolumn{3}{|c|}{$\begin{array}{l}\text { Limits for quality of tracks in } \\
\text { curves of small radius }\end{array}$} & \multicolumn{3}{|c|}{$\begin{array}{l}\text { Limits for quality of track } \\
\text { in the corners of a large } \\
\text { radius and the direction }\end{array}$} \\
\hline & $\begin{array}{l}\text { QN1 } \\
{[\mathrm{mm}]}\end{array}$ & $\begin{array}{l}\text { QN2 } \\
{[\mathrm{mm}]}\end{array}$ & $\begin{array}{l}\text { QN3 } \\
{[\mathrm{mm}]}\end{array}$ & $\begin{array}{l}\text { QN1 } \\
{[\mathrm{mm}]}\end{array}$ & $\begin{array}{l}\mathrm{QN} 2 \\
{[\mathrm{~mm}]}\end{array}$ & $\begin{array}{l}\text { QN3 } \\
{[\mathrm{mm}]}\end{array}$ \\
\hline $\begin{array}{l}\text { Standard deviation by profile } \\
\text { (z-deviation, irregularities): - } \sigma z\end{array}$ & 1.8 & 2.1 & 2.73 & 1.4 & 1.7 & 2.2 \\
\hline $\begin{array}{l}\text { Standard deviation in direction (y- } \\
\text { deviation): - } \sigma \mathrm{y}\end{array}$ & 1,2 & 1.5 & 1.95 & 1.0 & 1.3 & 1.7 \\
\hline $\begin{array}{l}\text { Maximum single deviation per } \\
\text { profile, irregularities: } Z \max \end{array}$ & 8.0 & 12,0 & 15.6 & 6.0 & 10 & 13,0 \\
\hline $\begin{array}{l}\text { Maximum single deviation per } \\
\text { direction - Ymax }\end{array}$ & 8.0 & 10,0 & 13,0 & 6.0 & 8.0 & 0.4 \\
\hline
\end{tabular}

The geometric quality of the track from the standpoint of maintenance criteria is defined in three levels:

- QN 1 value, which results from the track control or from the rate of maintenance in the context of the normal planning tasks of maintenance rails.

- QN 2 value, which results from short-term measures to maintain track.

- QN 3 value, in which exceedances are observed, track segment is excluded from the tests because the geometrical quality of track is not typical of tracks quality. This value still doesn't correspond to the most unfavorable condition, but it is an allowed form the aspect of maintenance.

\subsection{Test Train Composition and Condition}

Set of diesel engine train is composed of two motor wagons for passengers, which are attached by clutch. Figure 1 .

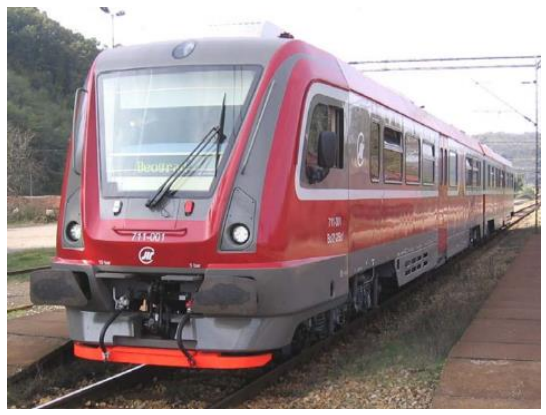

Figure 1

Diesel engine train series 711, equipped with measuring devices 
The train was tested in the ready for service mode. The mass of a motor vehicle with toilet is $44.019 \mathrm{~kg}$. Mass of train without toilets is $43,644 \mathrm{~kg}$. Total train mass is $87,663 \mathrm{~kg}$.

For testing purposes, 18 people boarded the train. If the average mass of passengers with luggage is $80 \mathrm{~kg}$, total mass of passengers was $1440 \mathrm{~kg}$, thus, the total mass of the train during testing was $89103 \mathrm{~kg}$. The rolling surfaces of wheels on a train have a UIC - ORE profile. Before the test, the train has passed about $1500 \mathrm{~km}$ so that the profiles of rolling surface of the wheels were a little worn. On Figure 3 is shown measuring points from acceleration.

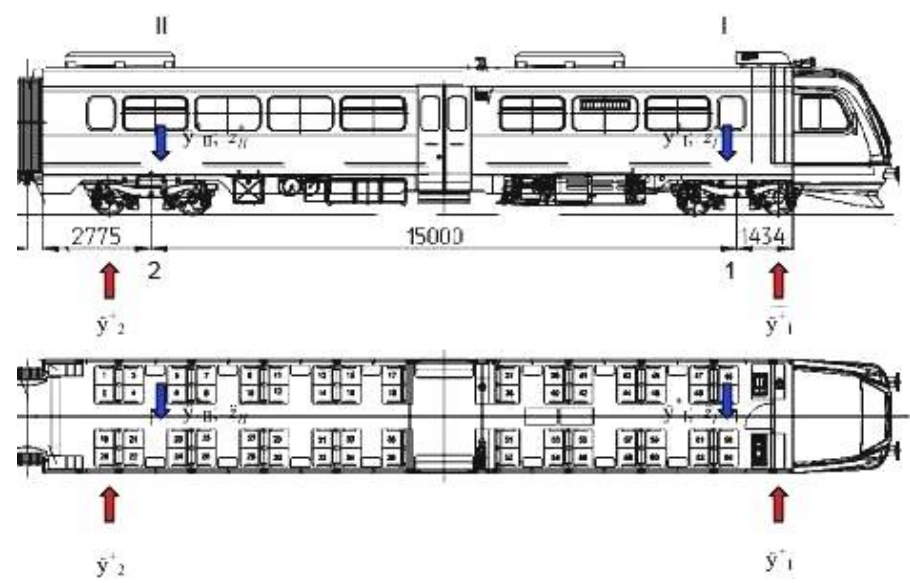

Figure 3

Sensors for acceleration setup

Red arrow are marked measuring points on the bogie frame abovethe axle and, a blue arrow are marks measuring at floor level above the central bogie pivot.

Lateral acceleration of bogie frame was measured (Figure 2), as well as lateral and vertical acceleration on train floor Figure 3. The measuring signals from the channels are shown in Table 2:

Table 2

Measuring signals from the channels

\begin{tabular}{|l|c|c|c|}
\hline \multicolumn{1}{|c|}{ Sizes } & Units & $\begin{array}{c}\text { Measuring } \\
\text { locations }\end{array}$ & $\begin{array}{c}\text { Filter when recording } \\
\text { to computer }\end{array}$ \\
\hline $\begin{array}{l}\text { Transverse acceleration of the frame } \\
\text { rotating stand above the front axle } \\
\text { assembly lead (drive) rotating stand }\end{array}$ & $\mathrm{m} / \mathrm{s}^{2}$ & 1 & $50 \mathrm{~Hz}$ \\
\hline $\begin{array}{l}\text { Transverse acceleration of the frame } \\
\text { rotating stand above the rear axle } \\
\begin{array}{l}\text { assembly medium (free) working } \\
\text { pedestals }\end{array}\end{array}$ & $\mathrm{m} / \mathrm{s}^{2}$ & 2 & $50 \mathrm{~Hz}$ \\
\hline
\end{tabular}




\begin{tabular}{|l|c|c|c|}
\hline \multicolumn{1}{|c|}{ Sizes } & Units & $\begin{array}{c}\text { Measuring } \\
\text { locations }\end{array}$ & $\begin{array}{c}\text { Filter when recording } \\
\text { to computer }\end{array}$ \\
\hline $\begin{array}{l}\text { Transverse acceleration in the axis } \\
\text { of the crate above the lead (drive) } \\
\text { bolt rotating stand }\end{array}$ & $\mathrm{m} / \mathrm{s} 2$ & I & $50 \mathrm{~Hz}$ \\
\hline $\begin{array}{l}\text { Transverse acceleration in the axis } \\
\text { of the crate above the rear pivot of } \\
\text { the middle (free) pivot pedestals }\end{array}$ & $\mathrm{m} / \mathrm{s} 2$ & II & $50 \mathrm{~Hz}$ \\
\hline $\begin{array}{l}\text { Vertical acceleration in the axis of } \\
\text { the crate above the lead (drive) bolt } \\
\text { rotating stand }\end{array}$ & $\mathrm{m} / \mathrm{s} 2$ & I & $50 \mathrm{~Hz}$ \\
\hline $\begin{array}{l}\text { Vertical acceleration in the axis of } \\
\text { the crate above the bolt of medium } \\
\text { (free) rotating stand }\end{array}$ & $\mathrm{m} / \mathrm{s} 2$ & II & $50 \mathrm{~Hz}$ \\
\hline Driving speed & $\mathrm{km} / \mathrm{h}$ & - & $50 \mathrm{~Hz}$ \\
\hline Road trip & $\mathrm{m}$ & - & $50 \mathrm{~Hz}$ \\
\hline
\end{tabular}

During the recording, measurement signals were sampled at a frequency of $300 \mathrm{~Hz}$. Measurement signals of acceleration and speed are provided in Table 3.

Table 3

Measuring equipment

\begin{tabular}{|l|l|l|l|}
\hline \multicolumn{1}{|c|}{ Name } & \multicolumn{1}{c|}{ Type } & \multicolumn{1}{c|}{ Number } & Manufacturer \\
\hline Encoder acceleration 1 & V 12/200 & 074510716 & HBM \\
\hline Encoder acceleration 2 & V 12/200 & 7321 & HBM \\
\hline Encoder acceleration 3 & V 12/200 & 3047 & HBM \\
\hline Encoder acceleration 4 & V 12/200 & 3052 & HBM \\
\hline Encoder acceleration 5 & V 12/200 & 3290 & HBM \\
\hline Encoder acceleration 6 & V 12/200 & 074510708 & HBM \\
\hline Impulse encoder & Faively & 5030 & ESPAS \\
\hline Measuring acquisition system & Quantum X MX 840 & 000955001B2D & HBM \\
\hline Computer & Notebook & & DELL \\
\hline
\end{tabular}

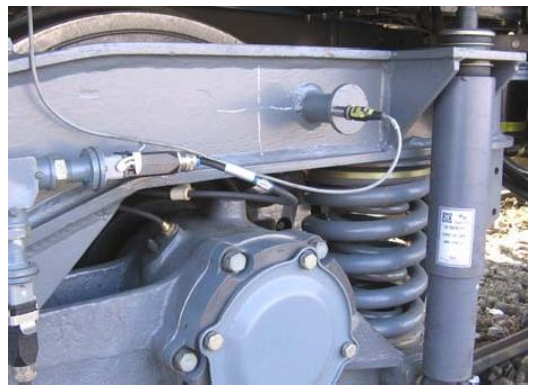

Figure 2

The encoder of acceleration on the frame rotating by - century and above the outer shaft signal 


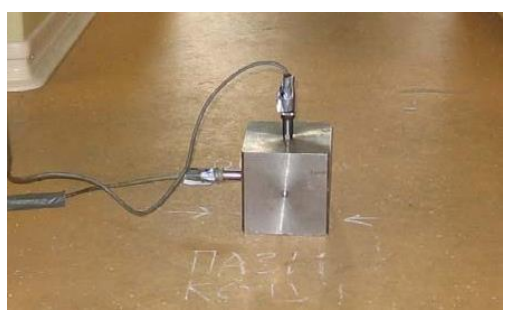

Figure 3

Sensors of acceleration above the main pivot

The characteristics of the measuring equipment used are given in Table 4.

Table 4

Characteristics of measuring equipment

\begin{tabular}{|l|c|}
\hline \multicolumn{1}{|c|}{ Size } & Extended measurement uncertainty \\
\hline Speed up & $\pm 0,43 \%$ \\
\hline Speed & $\leq 0.1 \%$ \\
\hline
\end{tabular}

\section{Test Results}

The test results are, in the following order:

1) Track sections with directions and curves of very large radius $R \geq 2500 \mathrm{~m}$

- motor car 1 forward

- motor car 1 back

2) Track sections with curves of large radius $600 \mathrm{~m} \leq \mathrm{R}<2500 \mathrm{~m}$

- motor car 1 forward

- motor car 1 back

3) Track sections with curves of small radius $400 \mathrm{~m} \leq \mathrm{R}<600 \mathrm{~m}$

- $\quad$ motor car 1 forward

- motor car 1 back

4) Track sections with curves of very small radius $250 \mathrm{~m} \leq \mathrm{R}<400 \mathrm{~m}$

- $\quad$ motor car 1 forward

- $\quad$ motor car 1 back

The maximum recorded speed driving on a track section was $112.8 \mathrm{~km} / \mathrm{h}$. Since minimum speed of $105 \mathrm{~km} / \mathrm{h}$ was not achieved at this section, the criterion for running speed in test area 1 was reduced to $103 \mathrm{~km} / \mathrm{h}$. Criterion of the overshoot $\mathrm{Cd} \leq 40 \mathrm{~mm}$ was fulfilled during driving in the right curvature radius of $5000 \mathrm{~m}$. 
All mathematical expectations of running safety parameters are well below the limit values. The smallest reached factor of safety $-\lambda$ min is 2.24 for the transverse acceleration above the central pivot of the bogie.

Measuring sections for statistical processing in the test area are presented in Table 5.

Table 5

Test results, measuring sequences for statistical data analyses

\begin{tabular}{|c|c|c|c|c|c|c|c|}
\hline \multirow{2}{*}{$\begin{array}{l}\text { Nr. } \\
\text { The sections }\end{array}$} & \multicolumn{2}{|c|}{ Stationary } & \multirow{2}{*}{$\begin{array}{c}1 \\
{[\mathrm{~m}]}\end{array}$} & \multirow{2}{*}{$\begin{array}{c}\mathrm{R} \\
{[\mathrm{m}]}\end{array}$} & \multirow{2}{*}{$\begin{array}{c}\mathrm{h} \\
{[\mathrm{mm}]}\end{array}$} & \multirow{2}{*}{$\begin{array}{c}\text { In P } \\
{[\mathrm{km} / \mathrm{h}]}\end{array}$} & \multirow{2}{*}{$\begin{array}{c}\mathrm{Cd} \\
{[\mathrm{mm}]}\end{array}$} \\
\hline & $\begin{array}{c}\text { From the } \\
{[\mathrm{km} . \mathrm{m}]}\end{array}$ & \begin{tabular}{|c} 
To \\
{$[\mathrm{km} \cdot \mathrm{m}]$}
\end{tabular} & & & & & \\
\hline \multicolumn{8}{|c|}{ Section: A } \\
\hline 1 & 2 & 3 & 4 & 5 & 6 & 7 & 8 \\
\hline 1 & 61.774 & 62.524 & 250 & $\infty$ & - & 111.9 & - \\
\hline 2 & 61.524 & 61.274 & 250 & $\infty$ & - & 110.6 & - \\
\hline 3 & 61.274 & 61.024 & 250 & $\infty$ & - & 109.2 & - \\
\hline 4 & 61.024 & 60.774 & 250 & $\infty$ & - & 107.9 & - \\
\hline 5 & 60.774 & 60.524 & 250 & $\infty$ & - & 107.4 & - \\
\hline 6 & 60.524 & 60.274 & 250 & $\infty$ & - & 107.5 & - \\
\hline 7 & 60.274 & 60.024 & 250 & $\infty$ & - & 107.4 & - \\
\hline 8 & 60.024 & 59.774 & 250 & $\infty$ & - & 107.8 & - \\
\hline 9 & 59.774 & 59.524 & 250 & $\infty$ & - & 108.8 & - \\
\hline 10 & 59.524 & 59.274 & 250 & $\infty$ & - & 110.8 & - \\
\hline 11 & 59.274 & 59.024 & 250 & $\infty$ & - & 112.1 & - \\
\hline 12 & 59.024 & 58.774 & 250 & $\infty$ & - & 112.4 & - \\
\hline 13 & 58.774 & 58.524 & 250 & $\infty$ & - & 112.6 & - \\
\hline 14 & 58.524 & 58.274 & 250 & $\infty$ & - & 112.8 & - \\
\hline 15 & 58.274 & 58.024 & 250 & $\infty$ & - & 112.3 & - \\
\hline 16 & 58.024 & 57.774 & 250 & $\infty$ & - & 112.4 & - \\
\hline 17 & 57.774 & 57.524 & 250 & $\infty$ & - & 112.9 & - \\
\hline 18 & 57.524 & 57.274 & 250 & $\infty$ & - & 112.8 & - \\
\hline 19 & 57.118 & 56.868 & 250 & $5000 / \mathrm{D}$ & 0 & 111.1 & 29 \\
\hline 20 & 56.868 & 56.618 & 250 & $5000 / \mathrm{D}$ & 0 & 110.5 & 29 \\
\hline 21 & 56.618 & 56.368 & 250 & $5000 / \mathrm{D}$ & 0 & 109.7 & 28 \\
\hline 22 & 56.368 & 56.118 & 250 & $5000 / \mathrm{D}$ & 0 & 109.0 & 28 \\
\hline 23 & 56.118 & 55.868 & 250 & $5000 / \mathrm{D}$ & 0 & 109.2 & 28 \\
\hline 24 & 55.868 & 55.618 & 250 & $5000 / \mathrm{D}$ & 0 & 110.0 & 29 \\
\hline 25 & 55.618 & 55.368 & 250 & $5000 / \mathrm{D}$ & 0 & 110.2 & 29 \\
\hline 26 & 55.368 & 55.118 & 250 & $5000 / \mathrm{D}$ & 0 & 110.3 & 29 \\
\hline 27 & 55.118 & 54.868 & 250 & $5000 / \mathrm{D}$ & 0 & 109.2 & 28 \\
\hline 28 & 219.600 & 219.850 & 250 & $\infty$ & - & 104.2 & \\
\hline
\end{tabular}




\begin{tabular}{|c|c|c|c|c|c|c|c|}
\hline \multirow{2}{*}{$\begin{array}{c}\text { Nr. } \\
\text { The sections }\end{array}$} & \multicolumn{2}{|c|}{ Stationary } & \multirow{2}{*}{$\begin{array}{c}1 \\
{[\mathrm{~m}]}\end{array}$} & \multirow{2}{*}{$\begin{array}{c}\mathrm{R} \\
{[\mathrm{m}]}\end{array}$} & \multirow{2}{*}{$\begin{array}{c}\mathrm{h} \\
{[\mathrm{mm}]}\end{array}$} & \multirow{2}{*}{$\begin{array}{c}\text { In P } \\
{[\mathrm{km} / \mathrm{h}]}\end{array}$} & \multirow{2}{*}{$\begin{array}{c}\mathrm{Cd} \\
{[\mathrm{mm}]}\end{array}$} \\
\hline & $\begin{array}{c}\text { From the } \\
{[\mathrm{km} . \mathrm{m}]}\end{array}$ & $\begin{array}{c}\text { To } \\
{[\mathrm{km} \cdot \mathrm{m}]}\end{array}$ & & & & & \\
\hline 29 & 217.100 & 217.350 & 250 & $\infty$ & & 105.3 & \\
\hline 30 & 216.850 & 217.100 & 250 & $\infty$ & & 104 & \\
\hline 31 & 215.850 & 216.100 & 250 & $\infty$ & & 103.6 & \\
\hline
\end{tabular}

All mathematical expectations of dynamic behavior parameters are below the limit values. The smallest reached factor of safety $-\lambda \min$ is 1.39 for the effective value of the transverse acceleration of the bogie.

\section{Discussion}

Testing of diesel engine train Series 711 working abilities verification was performed by program test security running and the quality of driving. Testing was carried out by a simplified method, by measuring the acceleration on the bogie frames.

Tests have included all test areas, i.e. categories of curves, which are provided by standards EN 14363 considering number and total length of the rail track sequence that meets the requirements of the standard.

Maximum speeds are reaching a value of $112.8 \mathrm{~km} / \mathrm{h}$, weather conditions during testing, and the state of rail have been appropriate. All mathematical expectation of parameters for secure train running are below the limit value in all test areas.

On the basis of the results of testing, it was concluded that the diesel engine train series 711, product of "Metrovagonmaš" with respect to operational safety and dynamic behavior, during determined test conditions, meets the prescribed requirements of the standard EN 14363: 2005.

\section{References}

[1] Scheepmaker, G. M., Willeboordse, H. Y., Hoogenraad, J. H., Luijt, R. S., \& Goverde, R. M. (2019) Comparing train driving strategies on multiple key performance indicators. Journal of Rail Transport Planning \& Management, 100163

[2] Fernández-Rodríguez, A., Fernández-Cardador, A., \& Cucala, A. P. (2018) Balancing energy consumption and risk of delay in high speed trains: A three-objective real-time eco-driving algorithm with fuzzy parameters. Transportation Research Part C: Emerging Technologies, 95, 652-678

[3] Cheng, R., Chen, D., Cheng, B., \& Zheng, S. (2017) Intelligent driving methods based on expert knowledge and online optimization for high-speed trains. Expert Systems with Applications, 87, 228-239 
[4] Fernandez-Rodriguez, A., Fernández-Cardador, A., \& Cucala, A. P. (2018) Real time eco-driving of high speed trains by simulation-based dynamic multi-objective optimization. Simulation Modelling Practice and Theory, 84, $50-68$

[5] Naweed, A. (2014) Investigations into the skills of modern and traditional train driving. Applied ergonomics, 45(3), 462-470

[6] Kozina, A., Radica, G., \& Nižetić, S. (2020) Analysis of methods towards reduction of harmful pollutants from Diesel engines. Journal of Cleaner Production, 121105

[7] Domínguez-Sáez, A., Rattá, G. A., \& Barrios, C. C. (2018) Prediction of exhaust emission in transient conditions of a diesel engine fueled with animal fat using Artificial Neural Network and Symbolic Regression. Energy, 149, $675-683$

[8] Nikzadfar, K., \& Shamekhi, A. H. (2019) Investigating a new model-based calibration procedure for optimizing the emissions and performance of a turbocharged diesel engine. Fuel, 242, 455-469

[9] Németh, A., \& Fischer, S. (2021) Investigation of the glued insulated rail joints applied to cwr tracks. Facta Universitatis, Series: Mechanical Engineering, doi: 10.22190/FUME210331040N

[10] Shatrov, Mikhail G. et al. Influence of pressure oscillations in common rail injector on fuel injection rate. Facta Universitatis, Series: Mechanical Engineering, [S.1.], v. 18, n. 4, pp. 579-593, Dec. 2020

[11] Shatrov, Mikhail G. et al. Method of conversion of high- and middle-speed diesel engines into gas diesel engines. Facta Universitatis, Series: Mechanical Engineering, [S.1.], v. 15, n. 3, pp. 383-395, Dec. 2017

[12] Sinyavski, V., Shatrov, M., Kremnev, V., \& Pronchenko, G. (2020) Forecasting of a boosted locomotive gas diesel engine parameters with oneand two-stage charging systems. Reports in Mechanical Engineering, 1(1), 192-19

[13] S. Fischer, Investigation of effect of water content on railway granular supplementary layers, Naukovyi Visnyk Natsionalnoho Hirnychoho Universytetu, ISSN 2071-2227, E-ISSN 2223-2362, 2021, № 3, doi.org/10.33271/nvngu/2021-3/064

[14] Sysyn, M., Nabochenko, O., Kovalchuk, V., Przybyłowicz, M., \& Fischer, S. (2021) Investigation of interlocking effect of crushed stone ballast during dynamic loading. Reports in Mechanical Engineering, 2(1), 65-76, https://doi.org/10.31181/rme200102065s

[15] Kuchak, A. J. T., Marinkovic, D., Zehn, M. Parametric Investigation of a Rail Damper Design Based on a Lab-Scaled Model (2021) Journal of Vibration Engineering and Technologies, 9 (1), pp. 51-60 
[16] Tigh Kuchak, A. J., Marinkovic, D., Zehn, M. Finite element model updating - Case study of a rail damper (2020) Structural Engineering and Mechanics, 73 (1), pp. 27-35 